\title{
Habitat of mammals in West Java, Indonesia
}

\author{
ERRI N. MEGANTARA ${ }^{1,2,3}$, SYA SYA SHANIDA ${ }^{3, \bullet}$, TEGUH HUSODO ${ }^{1,2,3}$, PUPUT FEBRIANTO $^{2,3}$, \\ M. PAHLA PUJIANTO ${ }^{3}$, RANDI HENDRAWAN ${ }^{3}$ \\ ${ }^{1}$ Department of Biology, Faculty of Mathematics and Natural Sciences, Universitas Padjadjaran. Jl. Raya Bandung-Sumedang Km 21, Jatinangor, \\ Sumedang 45363, West Java, Indonesia \\ ${ }^{2}$ Program in Environmental Science, School of Graduates, Universitas Padjadjaran. Jl. Sekeloa, Coblong, Bandung 40134, West Java, Indonesia. \\ ${ }^{3}$ Center of Environment and Sustainable Science, Directorate of Research, Community Services and Innovation, Universitas Padjadjaran. Jl. Sekeloa, \\ Coblong, Bandung 40134, West Java, Indonesia. Tel.: +62-22-7797712, `e-mail: syasyashanida@ gmail.com
}

Manuscript received: 3 June 2019. Revision accepted: 29 October 2019.

\begin{abstract}
Megantara EN, Shanida SS, Husodo T, Febrianto P, Pujianto MP, Hendrawan R. 2019. Habitat of mammals in West Java, Indonesia. Biodiversitas 20: 3380-3390. West Java has various habitat types, natural forests and human-land modified. Based on previous studies by Padjadjaran University that mammals were found in several locations, such as Gunung Salak, Ciletuh, Cisokan, Kamojang, and Darajat. There are many mammals found in various habitat so that it is important to reveal the habitat types that are usually used by mammals to fulfill their daily needs. The purpose of this study is to reveal the habitat types that are most commonly found in mammal species. Semi-structured interviews, direct observations, camera trapping, sign survey, and collapsible trap installation were applied in this study. Based on the results of the study, Mammals in West Java were found in 54 species, 21 families, and nine orders. Natural forests found 38 species, while mammals found in human-land modified as many as 16 species. In human land modified, agroforestry found more mammal species compared to other human-land.
\end{abstract}

Keywords: Disturbances, land cover types, mammals

\section{INTRODUCTION}

Based on data from the West Java Forest Service, the forest area in West Java, Indonesia in 2017 is known to be a conservation forest of $139,790.08$ hectares, while protected forest area of $274,830.62$ hectares (Central Bureau of Statistic 2018). This shows that protected forests are more extensive than conservation forests. Most of the diversity and population ecology of medium and large mammals are targeted on National Park and sanctuaries of the country (Kasso and Bekel 2014), but outside of the protected areas records and conservation status of the different species of mammals are poorly known (Rabira et al. 2015). Various efforts to conserve mammals are still focused on natural ecosystems, such as forests. There has not been much research on mammals carried out specifically in non-conservation forest areas, whereas many regions in Indonesia have extensive community lands in the landscape and are directed to be areas that have a conservation function, besides still functioning as a production system (Husodo et al. 2019a).

The forest area as a habitat for most mammals tends to be concentrated in the Southern part of West Java which stretches from Sukabumi, Cianjur, Bandung, Garut, Sumedang, Tasikmalaya, Kuningan, and spreads to small parts in Purwakarta, and Subang (West Java Regional Environmental Management Agency 2008). Among these areas, Cisokan, Ciletuh, Kamojang, Darajat, and Gunung Salak are known to have various species of mammals based on previous studies by Padjadjaran University that published by Husodo et al. (2019c) about mammalian diversity in West Java, Indonesia. The previous publication tends to reveal about mammals' diversity and comparison of the results of biodiversity studies from 2007-2018 in West Java, especially Ciletuh, Cisokan, Kamojang, Darajat, and Gunung Salak. But, those studies haven't revealed about mammals' habitat in West Java so that the information of mammals in this study is important to reveal.

Some study areas are located in the non-conservation forest areas in West Java, which are not protected by regional protection regulations. This unprotected area is inhabited by species of mammals that are protected both by national and international regulations. Besides that, the presence of endangered mammals in that unprotected area in West Java that has high anthropogenic factors will certainly increase the chances of local extinction (Husodo et al. 2019c). Many larger mammals are extinct on the island or have a highly fragmented distribution (Nijman 2013), putting enormous pressure on biodiversity (Miettinen et al. 2011). Threats include forest decline but also trade in wild animals for pets, traditional medicine or other economic uses (Rode-Margono et al. 2014). In the previous study, it was known that several species of mammals with high conservation status, such as the Javan leopard (Panthera pardus melas), Silvery gibbon (Hylobates moloch), Malayan pangolin (Manis javanica), and many more are existing in these areas. 


\section{MATERIALS AND METHODS}

\section{Study area}

The study was conducted in five locations on West Java in 2017-2018, including Cisokan in West Bandung District, Ciletuh in Sukabumi District, Kamojang and Darajat in Garut District, and Gunung Salak between Sukabumi and Bogor District, West Java, Indonesia. The study location can be seen in Figure 1. West Java Province is divided into steep mountainous regions in the South with an altitude of more than 1500 masl, the area of the hillsides in the middle part of West Java with an altitude of 100-1500 masl, area in the North with an altitude of $0-10 \mathrm{~m}$ asl. West Java is located between $5^{\circ} 50^{\prime}-7^{\circ} 50^{\prime} \mathrm{SL}$ and $104^{\circ} 48^{\prime}-108^{\circ} 48^{\prime} \mathrm{EL}$. The area of West Java is $35,377.76 \mathrm{~km}^{2}$. The Northern part of West Java Province is bordered by the Javan Sea, the Southern part is bordered by the Indian Ocean, the Western part is bordered by Banten Province and DKI Jakarta Province, and the Eastern part is bordered by Central Java Province (Central Bureau of Statistic 2018).

\section{Natural forest}

Based on vegetation aspect, it has a formation of lowland forest vegetation, characterized by famous species such as kondang (Ficus variegata), tereup (Artocarpus elastica), kepuh (Sterculia foetida), and ki hampelas (Ficus hampelas).

\section{Production forest}

The production forest also referred to monoculture forests, such as pine (Pinus merkusii), teak (Tectona grandis), and mahogany (Swietenia macrophylla). This forest is managed by Perhutani corporation.

\section{Riparian}

This riparian is located on the riverbank area, it has different type of vegetation structure and has several species of aquatic environmental indicators. The species of plants that exist, includes sisik penyu (Elatostema strigosa), teklan (Ageratina riparia), and cerem (Astronia spectabilis).

\section{Shrubs}

The shrubs of natural forest have been into huma or swidden cultivation, but it has been abandoned. Shrubs growth due to land use has been left without intensive management. The species of plants in shrubs, including kaliandra merah (Calliandra calothyrsus), kirinyuh (Austroeupatorium inufolium), and babadotan (Ageratum conyzoides).

\section{Agroforestry}

Agroforestry or talun is a land formed by a mixture of plant species of natural forests and gardens. The species of plants in talun are planted by the community to fulfill their needs. Species of plants in the talun, including sobsi (Maesopsis eminii), albasiah (Falcataria moluccana), and kawung (Arenga pinnata).

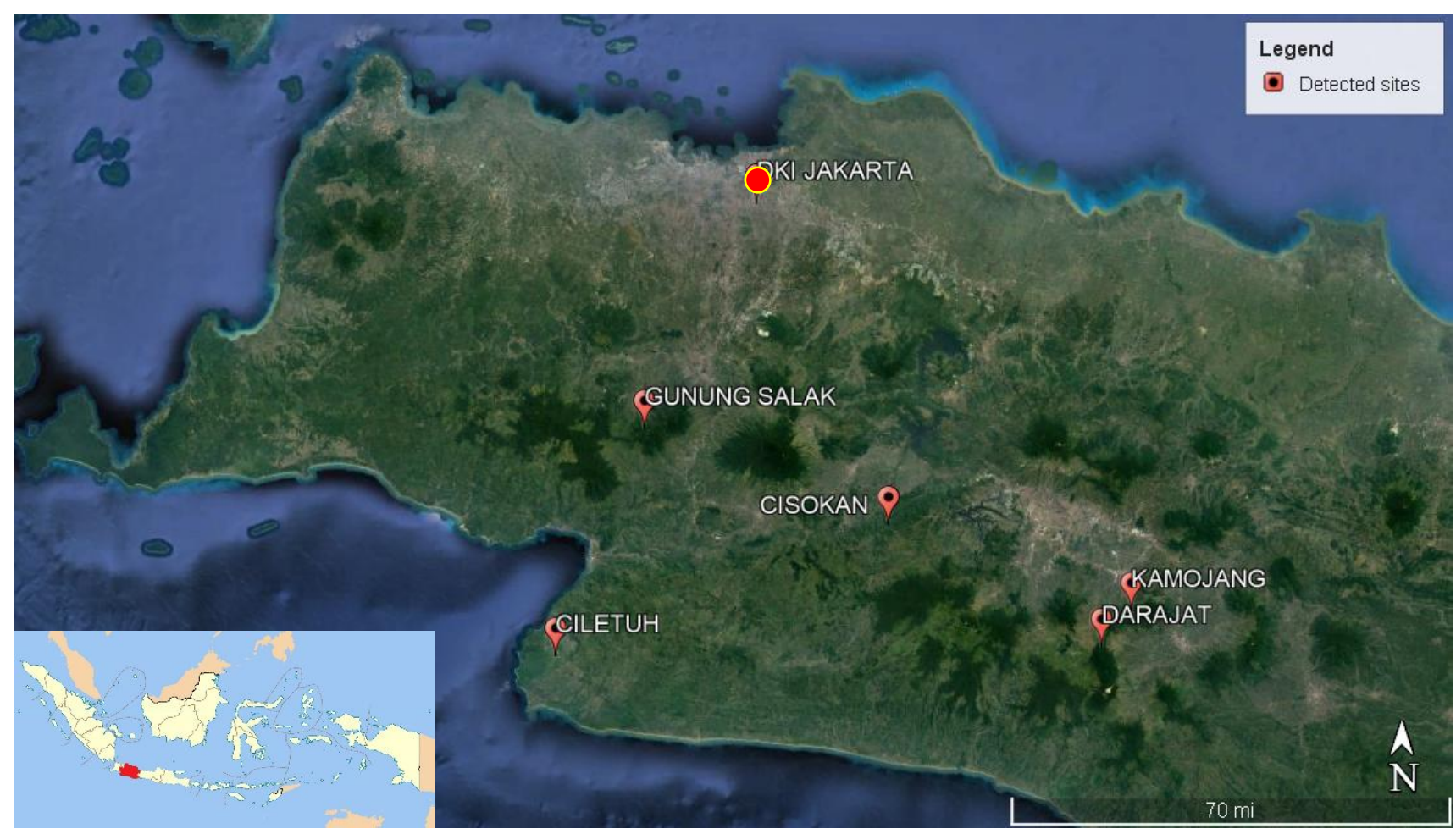

Figure 1. Study Areas in West Java, Indonesia; Cisokan (48 M 746030.02 m E 9231551.58 m S); Ciletuh (48 M 661159.73 m E 9198069.84 m S); Darajat (48 M 800811.68 m E 9200549.76 m S); Kamojang (48 M 808381.73 m E 9209763.04 m S); Gunung Salak (48 M 683756.00 m E 9255797.00 m S), and DKI Jakarta (48 M 712156.00 m E 9313039.00 m S). Source: Google Earth (2018) 


\section{Garden}

The gardens referred to monoculture gardens managed by the community, such as lemongrass (Cymbopogon citratus), ginger (Zingiber officinale), banana (Musa paradisiaca), and turmeric (Curcuma longa).

\section{Swidden cultivation}

This is managed intensively by the community. Management of huma is carried out by using fertilizers (organic and chemical) and land clearing from weeds. Not only rice (Oryza sativa var. Huma) is planted as secondary crops, such as cassava (Manihot utilissima).

\section{Rice field}

This land type is managed intensively by the community. Management of rice fields is carried out by using fertilizers (organic and chemical) and land clearing from weeds.

\section{Park}

This park as an artificial ecosystem is referred to a greening location inside the PT. Indonesia Power, Gunung Salak. The species of plants are natural plants, woody plants, road protection plants, decorative plants, and plants that have economic value.

\section{Procedures}

The data collection technique in this study was conducted by qualitative methods. Combining several methods, such as direct observation, camera trapping, collapsible trap, semi-structured interview, and sign survey (Husodo et al. 2019c). The study was conducted with a qualitative approach. The data were collected on 20172018 in the Cisokan (non-protected forest), Ciletuh Geopark (non-protected forest), Darajat (protected and non-protected forest), Kamojang (protected and nonprotected forest), and Gunung Salak (protected and nonprotected forest).

\section{Semi-structured interview}

Qualitative data collection is carried out by semistructured interviews. The semi-structured interview was taken by a deep interview with competent informants (local experts) (Iskandar et al. 2016). The interview was conducted with guidelines for interviews that had been made previously and could be developed during the interview. Informants were chosen by snowball sampling technique (Husodo et al. 2019c). The categorization of the informants in this study are poachers, community elders, and animal traders.

\section{Sign survey}

Sign surveys were conducted to find the existence of wild animals based on the existence that left behind, such as feces, footprints, scratches on the ground or trees, hairs, and leftovers. Fragoso et al. (2016), any sign of mammal species found, either directly or indirectly recorded about species, number, and location of the sign. Various signs of mammals' existence that was found should be measured and were documented. Indirect evidence is very useful when surveying animals such as carnivores that are naturally rare, elusive, found at low densities and difficult to capture repeatedly. So the presence of medium and large mammals was also been precisely indicated using indirect evidence, using sounds, spines, burrows and fecal droppings (Campos et al. 2013; Borges et al. 2014; Dereje et al. 2015). The burrow was identified based on signs such as footprints, quills, and feeding sites around the burrow (Mustikasari et al. 2019).

\section{Camera trapping}

Camera traps have been used for many ecological processes, including behavior, occupancy, biodiversity, and density (Burton et al. 2015). The analytical methods used to estimate these processes vary based on the specific objectives, sampling designs, and data recorded by ecologists (Keim et al. 2019). Camera-traps are widely used in South-East Asia for conservation and research. Particularly for inventorying ground-dwelling large mammal diversity within conservation landscapes (Phan et al. 2010; Moo et al. 2017) and estimating species density and abundance for conservation impact monitoring (Rayan and Mohamad 2009; Gray 2012; Gray and Prum 2012).

The installation of camera was carried out to optimize the observation time for 24 hours. Installation period at least two weeks using 16 units of the camera trap. Determination of camera trap installation based on the location recommended by the local community, the result of sign survey, and previous research, as well as based on presence signs to get wildlife encounter from camera trap. Cameras were set between 30 and $50 \mathrm{~cm}$ above the ground. All photographs were checked manually and mammal encounters with mammals identified to species by the author (Gray 2018). According to Sollman et al. (2013), the main survey areas that camera traps were set are active or abandoned logging roads, but the others were set randomly within the forest. We recorded the time of installation and retrieval of each camera and calculated the total duration of sampling (Debata and Kedar 2018).

\section{Direct observation}

Observations were made on mammals, including for bats, but no special method is used. Surveys in the sampled areas were performed twice a day, early in the morning (06.00 a.m.-08.00 a.m.) and late in the afternoon (5.00 p.m.-07.00 p.m.), when most mammals were more active in the study area (Meseret and Solomon 2014; Dereje et al. 2015), and at night (07.00 p.m.-10.00 p.m.). Signs of the mammal's existence that need to be considered include movement of tree branches and branches and sounds.

In the direct observations, animals were observed directly while walking along the transects (Dawd and Solomon 2013). An observer walks on foot along each transect and directly count all the individuals sighted with their respective species using unaided eyes and binocular. Information like species, the number of individuals, location, habitat type, sex, and age were recorded (Campos et al. 2013). In mammal vocalization procedures, mammals were identified through vocalizations heard (Dawd and Solomon 2013). 


\section{Collapsible trapping}

Collapsible traps are used for small mammals, such as collapsible Sherman traps and collapsible wire traps. For most terrestrial small mammals, Sherman's live trap has become a foldable, very portable and efficient trap of choice. The number of Sherman traps and wire trap is 15 for each trap. Trap installation was conducted only for two days at the determined sampling location. The bait used was peanut butter which had been mixed with oats and wrapped in gauze. Standard bait among many mammalogists is oatmeal flavored with peanut butter (Hoffmann et al. 2010).

For inventories of small terrestrial mammals, the easiest approach is to place traps at equal intervals along a line. Spacing distances are a function of habitat complexity. Traps in more complex habitats should be more closely placed (Hoffmann et al. 2010). We recommend that a trapline ideally be about $150 \mathrm{~m}$ long, with traps placed every 10 to $15 \mathrm{~m}$ (Hoffmann et al. 2010), but this design has to be adapted to the respective habitat conditions and target species. Whatever the spacing, to increase the trap success, traps should be placed at habitat features (e.g. log, rocks, tree, runways, burrows, bush clusters) as long as the point (Hoffmann et al. 2010).

\section{Data analysis}

Qualitative data collected by observation and semistructured. The data were analyzed by cross-checking to get valid data, summarizing, synthesizing, and making narration with descriptive and evaluative analysis (Iskandar 2018). Field identification of mammalian species was based on visible morphological characters of each mammalian species such as body size, color, proportion, and structure of organs like tail and ears (Dawd and Solomon 2013). Animals caught during the camera trap installation period and small mammals' trap and mammals track were identified using mammal's guidebook.

\section{RESULTS AND DISCUSSION}

\section{Mammals in various habitat types}

Mammals in Ciletuh, Cisokan, Kamojang, Darajat, and Gunung Salak were found are 54 species, 21 families, and nine orders (see Table 1) with details of three species of Artiodactyla, 12 species of Carnivores, seven species of Chiroptera, one species of Dermoptera, two species of Euphotyphla, one species of Pholidota, five species of Primates, 20 species of Rodentia, and three species of Scandentia. Information about the detection of each species, such as direct observation, sign surveys, interviews, collapsible traps, and camera trapping can be found in a previous publication by Husodo et al. (2019c).

Information on the presence of mammals through interviews is not shown in Table 1 . The results of the study in Table 1 are the species found through sign survey, direct observation, collapsible trapping, and camera trapping.

Based on the diversity of mammals in each study location, Ciletuh Geopark, especially Ciemas Subdistrict, were found 24 species, while Cisokan and Gunung Salak were found 30 species. Kamojang was found 31 species, and Darajat was found 19 species (Husodo et al. 2019c). The species of mammals are obtained either through direct observations or camera trapping, interviews with the community, catches using small mammalian traps, and signs of wildlife such as footprints and feces. Direct observation with mammals can be seen in Figure 2.

Several mammal species are not found during direct observation, sign survey, and camera traps, but its existences are known to be based on interviews from the local community, such as Indian muntjac (Muntiacus muntjak), Sunda stink badger (Mydaus javanensis), Javan ferret-badger (Melogale orientalis), binturong (Arctictis binturong), Sunda flying lemur (Galeopterus variegatus), and black flying squirrel (Aeromys tephromelas). The absence of these species is due to different local names from various regions, besides that the community provides little information about the details of color and morphology of mammal species due to brief direct observation.

Based on Figure 3, there are many mammals in West Java that are found in various habitat types, such as natural forests, riparian, settlements, production forests, rice fields, swidden cultivations or huma, gardens, agroforestry or taluns, shrubs, and parks. The number of mammal species in each habitat type also varies. Natural forests: 38 species, taluns: 19 species, riparian areas: 16 species, settlements: 12 species, shrubs: 12 species, production forests: 11 species, gardens: 7 species, rice fields: 6 species, parks: 3 species, and swidden cultivation: 1 species. As mentioned earlier, mammals are most commonly found in natural forests, afterward the agroforestry, whereas fewer mammals are found in huma.

Based on Table 1 mammals species can use many habitat types. Wild boar was found in eight habitat types, including natural forests, shrubs, riparians, taluns, gardens, rice fields, swidden cultivations, and production forests. This shows that wild boar has a high tolerance to the environment, especially the environment that has a high anthropogenic level. Wild boar's food always changes according to the seasons throughout the year, but the most consumed are fruits and grains (Kartono 2009).

The species found only in one habitat types, including Muntiacus muntjak, Herpestes javanicus, Martes flavigula, Prionodon linsang, Arctogalidia trivirgata, Paguma larvata, several species of Pteropodidae, Suncus murinus, Hylobates moloch, Lepus nigricollis, Petaurista petaurista, Petinomys sp., etc. (see Table 1). Habitat types used by these species are due to the need for feed sources in it. Besides, species such as Hylobates moloch have specific habitat needs, which occupy habitats with plant A stratification. Species found in only one habitat type do not indicate that these species use only one habitat type, it is necessary to study habitat use or a longer period. According to Duckworth et. al (2016), that genus of Prionodon has never been studied in the field. It is known only from records during general collecting expeditions and surveys, observation of captive animals, and study of museum material. Asian linsangs are rarely amongst the small carnivores most commonly recorded during a survey, regardless of the technique used (Duckworth et al. 2016). 
Table 1. Mammal species found in the various habitat types

\begin{tabular}{|c|c|c|c|c|c|c|c|c|c|c|c|}
\hline \multirow[b]{2}{*}{ Species } & \multirow[b]{2}{*}{ English name } & \multicolumn{10}{|c|}{ Habitat types } \\
\hline & & Natural forest & $\begin{array}{c}\text { Producti } \\
\text { on } \\
\text { forest }\end{array}$ & Riparian & Shrubs & Talun & Garden & $\begin{array}{c}\text { Swidden } \\
\text { Cultivati } \\
\text { on }\end{array}$ & $\begin{array}{l}\text { Rice } \\
\text { field }\end{array}$ & Park & $\begin{array}{c}\text { Settle- } \\
\text { ment }\end{array}$ \\
\hline \multicolumn{12}{|l|}{ ARTIODACTYLA } \\
\hline \multicolumn{12}{|l|}{ Cervidae } \\
\hline Muntiacus muntjak (Zimmermann, 1780) & Indian Muntjac & GS & & & & & & & & & \\
\hline \multicolumn{12}{|l|}{ Suidae } \\
\hline Sus scrofa (Linnaeus, 1758) & Wild Boar & $\begin{array}{l}\text { CLT, CSK, } \\
\text { KMJ, DRJ, GS }\end{array}$ & CSK & $\begin{array}{l}\text { CLT, DRJ, } \\
\text { GS }\end{array}$ & CLT & CLT, CSK & CLT, GS & CSK & CSK & & \\
\hline \multicolumn{12}{|l|}{ Tragulidae } \\
\hline Tragulus javanicus (Osbeck, 1765) & Lesser Mouse-Deer & CLT, GS & & GS & CSK & CSK & & & & & \\
\hline \multicolumn{12}{|l|}{ CARNIVORE } \\
\hline \multicolumn{12}{|l|}{ Felidae } \\
\hline Panthera pardus melas (Cuvier, 1809) & Javan Leopard & $\begin{array}{l}\text { CLT, CSK, } \\
\text { KMJ, GS }\end{array}$ & CSK & CSK & CSK & & & & CSK & & \\
\hline Prionailurus bengalensis (Kerr, 1792) & Leopard Cat & $\begin{array}{l}\text { CLT, CSK, } \\
\text { KMJ, DRJ, GS }\end{array}$ & CSK & CSK, DRJ & CLT & & & & CSK & & DRJ \\
\hline \multicolumn{12}{|l|}{ Herpestidae } \\
\hline $\begin{array}{l}\text { Herpestes javanicus (E. Geoffroy Saint-Hilaire, } \\
1818 \text { ) }\end{array}$ & Javan Mongoose & & & & CLT, CSK & & & & & & \\
\hline \multicolumn{12}{|l|}{ Mephitidae } \\
\hline Mydaus javanensis (Desmarest, 1820) & Sunda Stink Badger & & & & & & & & & & \\
\hline \multicolumn{12}{|l|}{ Mustelidae } \\
\hline Aonyx cinerea (Illiger, 1815) & Oriental Small-clawed Otter & & & CLT, CSK & & CSK & & & $\begin{array}{l}\text { CLT, } \\
\text { CSK }\end{array}$ & & CSK \\
\hline Martes flavigula (Boddaert, 1785) & Yellow-throated Marten & GS & & & & & & & & & \\
\hline Melogale orientalis (Horsfield, 1821) & Javan Ferret-badger & & & & & & & & & & \\
\hline \multicolumn{12}{|l|}{ Prionodontidae } \\
\hline Prionodon linsang (Hardwicke, 1821) & Banded Linsang & GS & & & & & & & & & \\
\hline \multicolumn{12}{|l|}{ Viverridae } \\
\hline Arctogalidia trivirgata (Gray, 1832) & Small-toothed Palm Civet & KMJ & & & & & & & & & \\
\hline Arctictis binturong (Raffles, 1821) & Binturong & & & & & & & & & & \\
\hline Paradoxurus hermaphroditus (Pallas, 1777) & Asian Palm Civet & CSK, DRJ, GS & & DRJ, GS & & CLT, CSK & CSK, GS & & & & $\begin{array}{l}\text { KMJ, } \\
\text { DRJ, GS }\end{array}$ \\
\hline $\begin{array}{l}\text { Viverricula indica (E. Geoffroy Saint-Hilaire, } \\
\text { 1803) }\end{array}$ & Small Indian Civet & & & & & CSK & CSK & & & & \\
\hline
\end{tabular}




\section{CHIROPTERA}

Pteropodidae

Cynopterus sphinx (Vahl. 1797)

Cynopterus brachyotis (Muller, 1838)

Hipposideros sp. (Gray, 1831)

Macroglossus minimus (E. Geoffroy, 1810)

Macroglossus sobrinus (Andersen, 1911)

Pteropus vampyrus (Linnaeus, 1758)

Rousettus amplexicaudatus (E. Geoffroy Saint-

Hilaire, 1810)

DERMOPTERA

Cynochepalidae

Galeopterus variegatus (Audebert, 1799) EULIPOTYPHLA

Soricidae

Suncus murinus (Linnaeus, 1758)

Suncus ater (Medway, 1965)

PHOLIDOTA

Manidae

Manis javanica (Desmarest, 1822)

PRIMATE

Cercopithecidae

Macaca fascicularis (Raffles, 1821)

Presbytis comata (Desmaret, 1822)

Trachypithecus auratus (E. Geoffroy, 1822)

Hylobatidae

Hylobates moloch (Audebert, 1798)

Lorisidae

Nycticebus javanicus (E. Geoffroy, 1812)

RODENTIA

Hystricidae

Hystrix javanica (Cuvier, 1823)

Leporidae

Lepus nigricollis (Cuvier, 1823)

Greater Short-nosed Indian

Fruit Bat

Lesser Short-nosed Fruit Bat

Roundleaf Bat

Gruit Bat $\quad$ CLT

Lesser Long-toothed Fruit Bat

Greater Long-tongued Fruit Bat

Large Flying Fox

(c)

Geoffroy's Rousette

CLT, GS

CSK

CSK

CSK

CSK

CSK

Sunda Flying Lemur

Asian House Shrew

Black Shrew

KMJ

CSK

Malayan Pangolin

CLT, CSK

CSK

CSK

CSK

Long-tailed Macaque

Grizzled Leaf Monkey

CLT, CSK, GS

CLT, CSK,

KMJ, DRJ, GS

Javan Langur

CLT, CSK,

DRJ, GS

Silvery Gibbon

CLT, CSK, GS

Javan Slow Loris

GS

GS

CLT, CSK CSK $\begin{array}{ll}\text { CSK } & \text { CSK } \\ \text { KMJ, DRJ CSK } & \text { CSK }\end{array}$

CLT, GS CSK

GS
Sunda Porcupine

CLT

Indian Hare

CSK 
Sciuridae

Aeromys tephromelas (Gunther, 1873)

Callosciurus nigrovittatus (Horsfield, 1823)

Callosciurus notatus (Boddaert, 1785)

Lariscus insignis (Cuvier, 1821)

Petaurista petaurista (Pallas, 1766)

Petinomys sp. (Thomas, 1908)

Ratufa bicolor (Sparman, 1778)

Sundasciurus lowii (Thomas, 1892)

Muridae

Chiropodomys gliroides (Blyth, 1856)

Hylomys suillus (Muller, 1840)

Maxomys surifer (Miller, 1900)

Niviventer lepturus (Jentink, 1879)

Black Flying Squirre

Black-striped Squirrel

Plantain Squirrel

GS CSK, KMJ

Three-striped Ground Squirrel GS

CLT, KMJ KMJ

Red Giant Fying Squirre

KMJ, DRJ, GS

Small Flying Squirrel

Black Giant Squirrel

Low's Squirrel

CSK

Pencil-tailed Tree Mouse

CLT

CSK

Short-tailed Gym Mousc

KMJ

Red Spiny Rat

KMJ, GS

Narrow-tailed White-bellied Rat KMJ

Rattus argentiventer (Robinson and Kloss, 1916) Rice-field Rat

CLT, KMJ

Polynesian Rat

Rattus tiomanicus jalorensis (Bonhote, 1903)

Malayan Field Rat

KMJ, DRJ

Rattus norvegicus (Berkenhout, 1769)

Brown Rat

House Rat

Rattus tiomanicus sabae (Miller, 1900)

Malayan Wood Rat

KMJ, DRJ, GS

RCANDENTIA

Tupaiidae

Tupaia glis (Diard \& Duvaucel, 1820)

Tupaia javanica (Horsfield, 1822)

Common Tree Shrew

Javan Tree Shrew

CLT, KMJ, DRJ

CLT, KMJ,

DRJ, GS

CLT, KMJ, DRJ

$\begin{array}{lcc}\text { Tupaia tana }(\text { Raffles, } 1821) & \text { Large Tree Shrew } & \text { CLT, KMJ, DRJ } \\ \text { Notes: CLT: Ciletuh Geopark, Ciemas District; CSK: Cisokan; KMJ: Kamojang; DRJ: Darajat; GS: Gunung Salak }\end{array}$

KMJ, DRJ

CLT, DRJ

KMJ

CLT

CSK

KM.

KMJ

KMJ

DRJ

KMJ

DRJ

KMJ

KM 

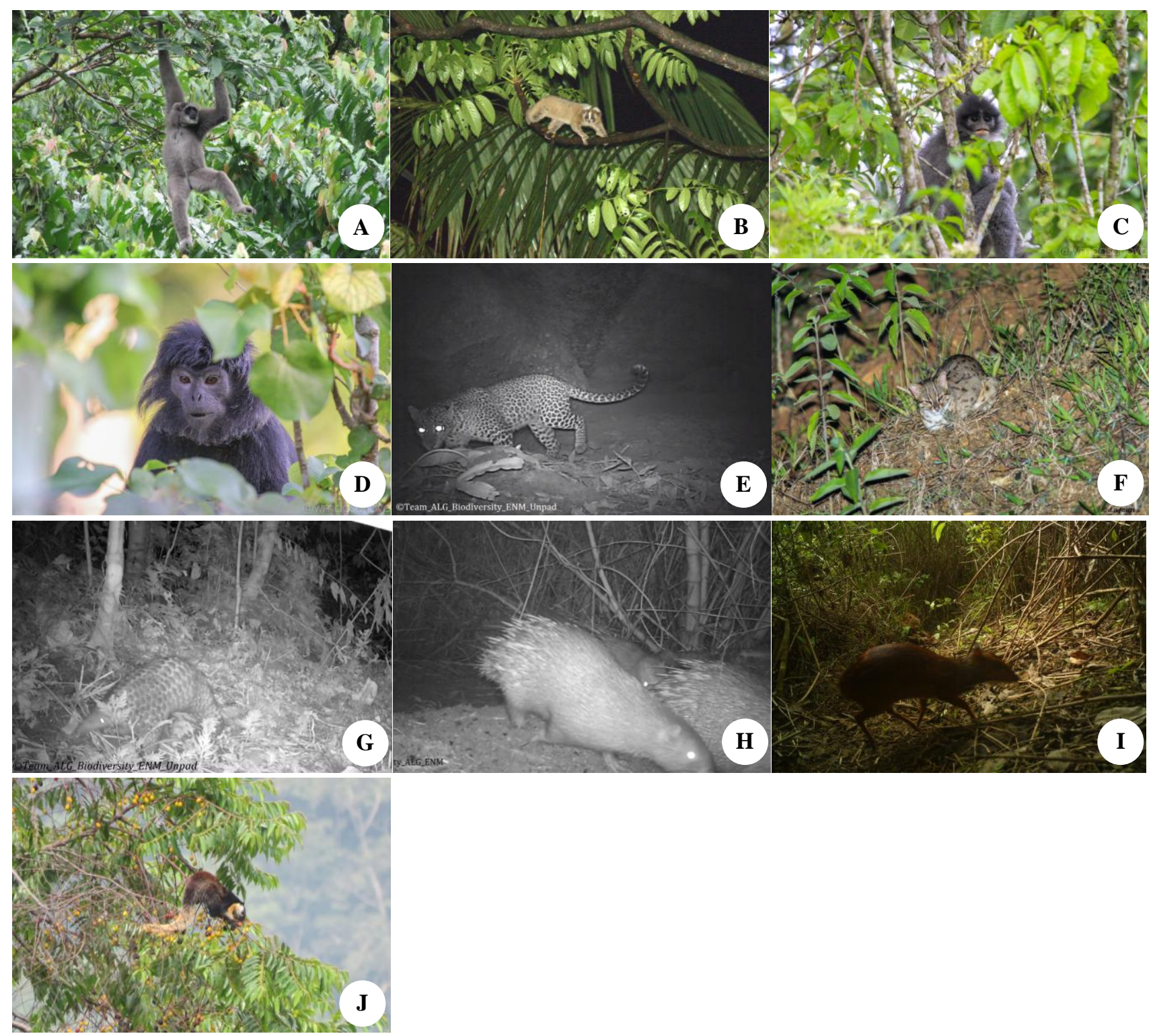

Figure 2. Mammals in West Java, Indonesia. A. Hylobates moloch, B. Nycticebus javanicus, C. Presbytis comata, D. Trachypithecus auratus, E. Panthera pardus melas, F. Prionailurus bengalensis, G. Manis javanica, H. Hystrix javanica, I. Tragulus javanicus, and J. Ratufa bicolor. Sources: Primary Data (2017-2018); Husodo et al. (2019c)

As mentioned in the previous paragraph that as many as 38 species are found in natural forest habitats with conditions that are still natural and far from human activity or little human presence. Other species found in humanland modified were found as many as 16 species, where talun found the most common types of mammals compared to other human land. In human land, species that have high conservation statuses, such as pangolin, Javan slow loris, and Javan leopard with Critically Endangered conservation status.

Based on the results of studies that leopards are found in the natural forest, production forest, talun, shrub, and rice fields. This shows that leopards have a low tolerance for environmental changes. The discovery of leopards in human land is assumed that leopards follow prey e.g. wild boar that look for food in the fields, huma, garden, and talun, as revealed by Shanida et al. (2018). Leopard's existence evidence was also found in a pine forest, which had an open canopy, lots of human activity, and lots of coffee plants. Leopard can use many different types of human-altered habitats, although their preference and main habitat appear to be a natural forest with little human disturbance (Shanida et al. 2018). The presence of Javan Leopard in human-land modified has the potential for conflict with humans. 


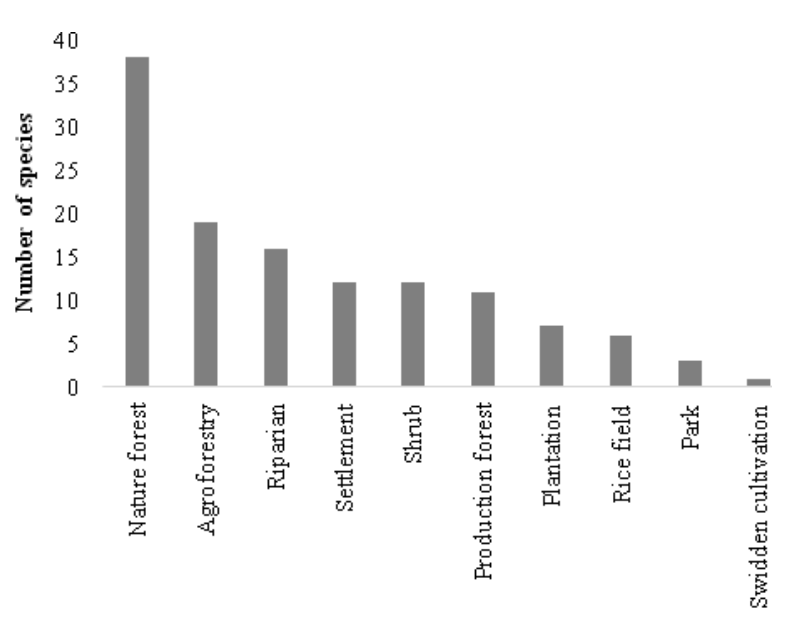

Habitat types

Figure 3. Total of mammal species found in each habitat types in West Java, Indonesia

Pangolins were found in the natural forest, riparian, and human-land modified, including production forests, talun, shrubs, and rice fields. According to Withaningsih et al. (2018), pangolin in Cisokan was found in the natural forest ecosystem, production forest, shrubs, and talun. In the production forest, which was dominantly grown by teak and mahogany trees, the traces of pangolin were found. The shrub vegetation usually appeared from abandoned huma or another upland agricultural land.

Javan slow loris was found in the natural forest, riparian, and human-land modified, including talun, shrubs, and settlement. According to Withaningsih et al. (2019), the existence of Javan slow lorises in fragmented habitats such as in bush habitats, talun and in areas surrounding the settlement, which were also talun, proved that these types of land use had the potential to become their habitat. The distribution of the slow lorises found in the settlements and talun was higher, even though both types of land use were locations with the highest intensity of human activity, thus increasing the opportunity for the lorises to be caught. The various types of feeding plants and the availability of bamboo or plants becoming the sleeping sites allowed the lorises to adapt well.

\section{Threats and disturbances of mammals}

In the ecosystem, biodiversity has important roles and functions in supporting human life. However, various human activities can also be a source of threats to biodiversity. Following are the threats and disturbances of mammals:

\section{Land-use changes}

The land has been converted into gardens, rice fields, etc. Land clearing is carried out by burning the forest so that the ash can be used as a natural fertilizer for rice fields or swidden cultivations. Besides, land clearing is carried out as tourist sites. As happened in Ciletuh-Palabuhanratu Geopark, large-scale land clearing for tourism needs was carried out, while Ciletuh has high mammal diversity. The land-use changes cause the loss of natural vegetation, thus changing the environmental condition. According to Husodo et al. (2019b), community land use has significantly impacted areas of previously forested slopes, mainly through slash-and-burn activities, with more permanent rice agriculture focused on the valley floors adjacent to the rivers. Cutting and burning of the vegetation usually result in not only the clearing of undergrowth but also forest trees, such as teak and pine.

Another case of land conversion is the construction of infrastructure, one of which is in Cisokan which is used as a dam as part of the planning for the construction of a Hydropower-Upper Cisokan Pumped Storage (UCPS). The existence of this dam certainly affects several important species, such as Aonyx cinerea, Prionailurus bengalensis, and other species that are located or use the river as their necessities. Not only the dam, but Cisokan also made access roads to facilitate vehicles that related to the construction. Besides, mammals that want to cross the roads will be hit by vehicles so it will reduce the mammal population. Besides, the existence of these access roads makes it easier for poachers to access the locations that were previously difficult to reach. Not only Cisokan, but infrastructures are also found in Kamojang, Gunung Salak, and Darajat so that human activities are high in these locations.

The land conversion as mammal habitat was going to be agricultural land, and infrastructures near the forest would have the chance of high human-mammalian conflict. As expressed by Partasasmita et al. (2016) that the Javan leopard began to enter the settlement of Girimukti Village in 1960 and continued in 2016. Leopards and human conflicts in Girimukti Village often occurred in 2013 by eating livestock, e.g. sheep that have usually grazed close to the forest, a location slightly distant from the area of permanent human settlement (Partasasmita et al. 2016).

The high activities for land clearing are due to the high economic needs of the community, but this land clearing is not followed by knowledge of environmental impacts so in several areas are potentially landslide. Not only threatening to mammals, but land clearing also causes loss or reduction in certain species of plants that are very important for mammals. The infrastructures certainly have the potential to cut off wildlife home range, cut off the availability of feed networks, reduce reproductive capacity and survival of various protected or endemic species.

\section{Hunting and trading of mammals}

Hunting and trading in mammals is the most common problem in the world because of the high market demand illegally and the lack of knowledge and law enforcement regarding the prohibition of hunting and trading in mammals, especially protected species. In the Cisokan, there is still a lot of hunting in certain species of mammals. Malayan porcupines, Malayan pangolins, and leopard cats in this region are the most hunted by poachers. Information about hunting in Cisokan was obtained through interviews.

According to Husodo et al. (2019b), communities pose a threat to local biodiversity because of hunting and collecting legal activities, unless involving protected 
species, and can be hard to control, especially if the monetary value of species is high. Such commercial collecting primarily targets species such as pangolin and a wide range of bird species which are popular in the pet trade. Pet trade also affects some of the primates, with especially Slow Loris being in high demand in South East Asian animal markets, but also other species such as leaf monkeys are traded.

Wildlife conflict also poses a threat to species, especially pigs and deer feeding on crops. Communities consider these species pests and hunt or trap them when they can. Indirectly this also affects predators such as Javan Leopard, for the disappearance of its prey forces it on occasions to feed on dogs or other domestic animals, with potentially fatal consequences for the leopard (Husodo et al. 2019b).

\section{Domestic waste}

Using pesticides or other chemicals on plants is also one of the factors that threaten the existence of mammals. Mammals use plants to obtain food to maintain their lives, one of which is Paradoxurus hermaphroditus. $P$. hermaphroditus is known to use coffee for feed. If the management of coffee plantation using the pesticides, it will endanger this species. Besides, rats that exposure to pesticides in rice fields and huma will be eaten by leopard cats as their prey, while chemical compounds in the rat's body will accumulate in the body of leopard cat. In the long term, it will certainly threaten the leopard cat population as a keystone species. Not only affects terrestrial organisms, but domestic waste especially chemicals will also pollute the waters, aquatic biota. Fish and crabs exposed to chemical compounds will certainly be eaten by smallclawed otter so that these chemical compounds will accumulate in the otter's body. These environmental impacts threaten the otter population itself over the long term.

\section{Noise}

The high level of human activities, such as Hydropower activities in Kamojang, Darajat, and Gunung Salak certainly produce sound pollution that will disturb certain mammals in communicating between groups and individuals, such as primates. Communication between groups and individuals is important to convey information about the existence of predators. Rabanal et al. (2010) revealed that noise generated from seismic surveys on mining projects has been proven to drive away wildlife. Noise by humans has been shown to have a potential negative impact on various wildlife species due to its ability to mask the sounds of animal behavior, encourage stress, repel animals, and change behavior. For example, increased vigilance activities and distractions of animals, resulting in killing and eating each other between animals or reducing the free time to do other activities (Chan and Blumstein 2011).

To maintain the mammal population in West Java, a biodiversity management plan need to be carried out, as implemented in Cisokan Hydropower, Cianjur, West Java. Further studies need to be carried out that can provide clearer guidance on how to protect and restore the environment (including habitat) around the sites, protect and manage the endangered biodiversity through adaptive approaches and ecosystem management (Husodo et al. 2019b).

In conclusion, in West Java, most mammals found in the natural forests as many as 38 species, while mammals found in human-land modified as many as 16 species. Sus scrofa can be found in various habitat types, including natural forests, shrubs, riparians, agroforestry, gardens, rice fields, swidden cultivations, and production forests. Threats and disturbances that occur in West Java, including landuse changes, hunting and trading, domestic waste, and noise.

\section{ACKNOWLEDGEMENTS}

Acknowledgments were given to Centre Environment for Sustainability Science (CESS) Padjadjaran University, Prof. Erri Noviar Megantara Academic Leadership Grant Padjadjaran University 2017-2018 who have supported this research, and the research team.

\section{REFERENCES}

Borges HLM, Calouro AM, Botelho ALM, Silveira M. 2014. Diversity and habitat preference of medium and large-sized mammals in an urban forest fragment of southwestern Amazon. Iheri Serie Zool. 104 (2): 168-174.

Burton AC, Neilson E, Moreira D, Ladle A, Steenweg R, Fisher JT, Bayne E, Boutin S. 2015. Wildlife camera trapping: a review and recommendations for linking surveys to ecological processes. J Appl Ecol 52: 675-85. DOI: 10.1111/1365-2664.12432.

Campos FS, Large ARB, Ribeirop PHP. 2013. Diversity of medium and large sized mammals in a Cerrado fragment of central Brazil. J Threat Taxa 5 (15): 4994-5001.

Central Bureau of Statistic-Statistics of Jawa Barat Province. 2018. Jawa Barat Province in Figure 2018. Central Bureau of Statistic-Statistics of Jawa Barat Province. Bandung. [Indonesian]

Chan AAYH, Blumstein DT. 2011. Attention, noise, and implications for wildlife conservation and management. Appl Anim Behav Sci 131: 17.

Dawd Y, Solomon Y. 2013. Mammals of the Mazie National Park, Southern Ethiopia. SINET: Eth J Sci 36 (1): 55-61.

Debata S, Kedar KS. 2018. Estimating mammalian diversity and relative abundance using camera traps in a tropical deciduous forest of Kuldiha Wildlife Sanctuary, eastern India. Mammal Stud 43: 45-53.

Dereje N, Tsegaye G, Tadese H. 2015. The diversity, distribution and relative abundance of medium and large-sized mammals in Baroye Controlled Hunting Area, Illubabor Zone, Southwest Ethiopia. Intl J Mol Evol Biodiv 5 (4): 1-9.

Duckworth JW, Samejima H, Semiadi G, Hearn AJ, Ross J, Fredriksson G, Cheyne SM, Heydon M, Augeri DM, Brodie J, Giordiano A, Nakashima Y, Boonratana R, Hon J, Marshall AJ, Mathai J, Macdonald DW, Belant JL, Kramer-Schadt S, Wilting A. 2016. Predicted distribution of banded linsang Prionodon linsang (Mammalia: Carnivora: Prionodontidae) on Borneo. Raffles Bull Zool Suppl 33: 71-77.

Fragoso JMV, Levi T, Oliveira LFB, Luzar JB, Overman H, Read JM, et al. 2016. Line transect surveys under detect terrestrial mammals: implications for the sustainability of subsistence hunting. PLoS ONE 11(4): e0152659. DOI: 10.1371/journal.pone.0152659.

Gray TNE, Prum S. 2012. Leopard density in postconflict Cambodia: evidence from spatially explicit capture-recapture. J Wildl Manag 76: 163-169. 
Gray TNE. 2012. Studying large mammals with imperfect detection: status and habitat preferences of wild cattle and large carnivores in eastern Cambodia. Biotropica 44: 531-536.

Gray TNE. 2018. Monitoring tropical forest ungulates using camera-trap data. J Zool. DOI: 10.1111/jzo.12547.

Hoffmann A, Decher J, Rovero F, Schaer J, Voigt C, Wibbelt G. 2010 Chapter 19: Field methods and techniques for monitoring mammals. In: Manual on field recording techniques and protocols for all taxa biodiversity inventories and monitoring. Abc Taxa Publisher, United Kingdom.

Husodo T, Febrianto P, Megantara EN, Shanida SS, Pujianto MP. 2019a Diversity of mammals in forest patches of Cisokan, Cianjur, West Java, Indonesia. Biodiversitas 20 (5): 1281-1288.

Husodo T, Shanida SS, Febrianto P, Pujianto MP, Megantara EN. 2019c. Mammalian diversity in West Java, Indonesia. Biodiversitas 20 (7): 1846-1858.

Husodo T, Shanida SS, Megantara EN. 2019b. Biodiversity management plan in the non-conservation area, Cisokan Hydropower Plan Area, Cianjur, West Java, Indonesia. Biodiversitas 20 (6): 1524-1536.

Iskandar J, Iskandar BS, Partasasmita R. 2016. Responses to Environmental and socio-economic changes in the Karangwangi Traditional Agroforestry System, South Cianjur, West Java. Biodiversitas 17 (1): 332-341.

Iskandar J, Iskandar BS. 2018. Ethnobiology, rice biodiversity and rice cultivation modernization: case study in Baduy and Naga community. J Biodjati 3 (1): 47-62.

Kartono AP, Gunawan, Maryanto I, Suharjono. 2009. Relationship of mammals with vegetations types in Gunung Ciremai National Park. Jurnal Biologi Indonesia 5 (3): 279-294. [Indonesia]

Kasso M, Bekel A. 2014. Threats to mammals on fragmented habitats around Asella Town, central Ethiopia. Intl J Biodiver 2014: ID 903898. DOI: 10.1155/2014/903898.

Keim JL, Lele SR, DeWitt RD, Fitzpatrick JJ, Jenni NS. 2019. Estimating the intensity of use by interacting predators and prey using camera traps. J Anim Ecol. DOI: 10.1111/1365-2656.12960.

Meseret C, Solomon Y. 2014. Diversity of medium and large-sized mammals in Borena-Sayint National Park, South Wollo, Ethiopia. Intl J Sci Bas Appl Res 15 (1): 95-106.

Miettinen J, Shi C, Liew SC. 2011. Deforestation rates in insular Southeast Asia between 2000 and 2010. Global Change Biol 17: 2261-2270.

Moo SSB, Froese, GZ, Gray TNE. 2017. First structured camera-trap surveys in Karen State, Myanmar, reveal high diversity of globally threatened mammals. Oryx. DOI: 10.1017/ S003060531600113.

Mustikasari IA, Withaningsih S, Meganatara EN, Husodo T, Parikesit. 2019. Population and distribution of Sunda porcupine (Hystrix javanica F. Cuvier, 1823) in designated area of Cisokan Hydropower, West Java, Indonesia. Biodiversitas 20 (3): 762-769.

Nijman V. 2013. One hundred years of solitude: effects of long-term forest fragmentation on the primate community of Java, Indonesia. In: Marsh LK, Chapman CA. (eds). Primates in fragments: complexity and resilience. Springer, New York.

Partasasmita R, Shanida SS, Iskandar J, Meganatara EN, Husodo T, Parikesit, Malone N. 2016. Human-leopard conflict in Girimukti Village, Sukabumi, Indonesia. Biodiversitas 17 (2): 783-790.

Phan C, Prum S, Gray TNE. 2010. Recent camera-trap records of globally threatened species from the Eastern Plains Landscape, Cambodia. Cambodian J Nat Hist 2: 89-93.

Rabanal LI, Kuehl HS, Mundry R, Robbins MM, Boesch C. 2010. Oil prospecting and its impact on large rainforest mammals in Loango National Park, Gabon. Biological Conservation. 143: 1017-1024.

Rabira G, Tsegaye G, Tadesse H. 2015. The diversity, abundance, and habitat association of medium and large-sized mammals of Dati Wolel National Park, Western Ethiopia. Intl J Biodiv Conserv 7 (2): 112-118.

Rayan DM, Mohamad SW. 2009. The importance of selectively logged forests for tiger Panthera tigris conservation: a population density estimate in Peninsular Malaysia. Oryx 43: 48-51.

Rode-Margono EJ, Voskamp A, Spaan D, Lehtinen JK, Roberts PD, Nijman V, Nekaris KAI. 2014. Records of small carnivores and of medium-sized nocturnal mammals on Java. Small Carniv Conserv 50: 1-11.

Shanida SS, Partasasmita R, Hudoso T. Parikesit, Febriato P, Meganatara EN. 2018. Short Communication: The existence of Javan Leopard (Panthera pardus melas Cuvier, 1809) in the non-conservation forest areas of Cisokan, Cianjur, West Java, Indonesia. Biodiversitas 19 (1): 42-46. DOI: 10.13057/biodiv/d190107.

Sollmann R, Mohamed A, Samejima H, Wilting A. 2013. Risky business or simple solution-relative abundance indices from camera trapping. Biol Conserv 159: 405-412.

West Java Regional Environmental Management Agency. 2008. Environmental status in 2008. West Java Regional Environmental Management Agency. Bandung. [Indonesia].

Withaningsih S, Noorahya F, Megantara EN, Parikesit, Husodo T. 2018. Nest existences and population of Pangolin (Manis javanica Desmarest, 1822) at the designated area of Cisokan Hydropower, West Java, Indonesia. Biodiversitas 19 (1): 153-162.

Withaningsih S, Parikesit, Ayundari A, Prameswari G, Meganatara EN, Husodo T. 2019. Distribution and habitat of Javan slow loris (Nycticebus javanicus E. Geoffroy, 1812) in non-conservation area. AIP Publishing. 060006-1-060006-7. DOI: 10.1063/1.5061915. 